\section{Air quality and emergency pediatric care for symptoms of bronchial obstruction categorized by age bracket in Rio de Janeiro, Brazil}

\author{
Qualidade do ar e atendimentos pediátricos de \\ emergência por sintomas de obstrução brônquica \\ categorizados por faixas etárias no Rio de Janeiro, \\ Brasil
}

Marisa Moura 1

Washington Leite Junger 2

Gulnar Azevedo e Silva Mendonça 2

Antonio Ponce de Leon 2

\footnotetext{
${ }^{1}$ Escola Nacional de Saúde Pública Sergio Arouca, Fundação Oswaldo Cruz, Rio de Janeiro, Brasil. 2 Instituto de Medicina Social, Universidade do Estado do Rio de Janeiro, Rio de Janeiro, Brasil.

Correspondence M. Moura

Centro de Estudos da Saúde do Trabalhador e Ecologia Humana, Escola Nacional de Saúde Pública Sergio Arouca, Fundação Oswaldo Cruz. Rua Leopoldo Bulhões 1480 Rio de Janeiro, $R J$ 21041-210, Brasil. moura@ensp.fiocruz.br
}

\begin{abstract}
The objective of this study was to estimate the association between levels of air pollutants and respiratory symptoms in children. An ecological time-series study was conducted between April 2002 and March 2003 with daily data on $P_{10}$, $\mathrm{SO}_{2}, \mathrm{CO}, \mathrm{NO}_{2}$, and $\mathrm{O}_{3}$ and paediatric care in emergency rooms due to symptoms indicating bronchial obstruction. The potential confounding factors considered were: time trend, seasonality, meteorological variables, respiratory infections and the effects of weekends and holidays. A semi-parametric Poisson regression was used to model the time series. Splines (data smoothing functions), indicator variables and cubic polynomials were used to adjust the effects of the confounding variables. A 5\% significance level was adopted for the study. A statistically significant increase of $6.7 \%$ in paediatric visits of children of less than 2 years of age was associated with $\mathrm{PM}_{10}$. A 3\% positive association with $\mathrm{O}_{3}$ showed borderline significance $(p<0.06)$ in this age bracket. Our findings highlight the existence of an acknowledged public health problem in Rio de Janeiro, Brazil, and also emphasize the need to identify the principal sources of air pollutants.
\end{abstract}

Air Pollution; Asthma; Child

\section{Introduction}

Bronchial asthma is the most prevalent chronic disease in childhood, and its prevalence is increasing especially in large industrialized countries $1,2,3$. Although the disease has a low case fatality rate, it limits normal childhood activities in a large number of children. There are currently an estimated 300 million asthmatic individuals worldwide, a figure that will increase by another 100 million by the year 2025, due in part to the growing process of urbanization and air pollution 4 .

The contribution of air pollutants to the appearance of characteristic symptoms of bronchial asthma has still not been fully elucidated. Some evidence suggests that lesions in the airways and pulmonary parenchyma, caused by exposure to air pollutants, probably exacerbate the harmful effects of viruses and/or allergens 5,6.

Distinct levels of maturation and the anatomical development of the structures in the immune and pulmonary systems from birth to puberty determine the variations in responses to environmental stimuli. In the first years of life, the reduced size of the airways facilitates the decrease in the bronchial lumen during the inflammatory processes accompanying viral infections. At this age, the respiratory syncytial virus was found to be one of the most prevalent agents involved 7,8 . The respiratory manifestations are indistinguishable from the characteristic clinical 
picture of bronchial asthma, thus leading to constant errors in aetiological diagnoses ${ }^{9}$. From six years of age onwards, the temporal association with exposure to allergens, the recurrent evolution of acute clinical episodes, and the presence of specific biological parameters characterizing the immunological alterations of allergic diseases characterize children with bronchial asthma. Respiratory allergies and viral infections appear to be independent and synergistic risk factors for the development of symptoms of bronchial obstruction at this stage 8 .

Rio de Janeiro is the second largest city in Brazil, but the respiratory effects of air pollution on the paediatric population have received little investigation, while epidemiological data are scarce concerning the prevalence of bronchial asthma and other allergic diseases in the city's population 10 .

The objective of this present study was to estimate the association between daily variations in air pollutant levels and emergency room visits due to obstructive airway diseases in the paediatric population in a specific region of Rio de Janeiro city, considering different age groups.

\section{Material and methods}

The epidemiological design of a time series ecological study was adopted, with daily observation of health events, air pollutant concentrations, and meteorological factors.

All children from aged between one month and 12 years who had come for emergency medical treatment due to acute respiratory complaints, at public health units with a high daily volume of emergency medical care in the region of Jacarepaguá, city of Rio de Janeiro, between 1st April 2002 and 31 March 2003, were included in the study.

The study area is located in the west side of the city of Rio de Janeiro and covers $126.61 \mathrm{~km}^{2}$, with a paediatric population of 120,469 (Instituto Pereira Passos. Armazém de dados. http://portal geo.rio.rj.gov.br/serie_rfoco/municipio/index. htm, accessed on 03/Oct/2005).

A team of previously trained professionals conducted a daily selection of the patient treatment forms that met the eligibility criteria. After this stage, the presence of respiratory signs, symptoms, or diagnoses was recorded on an original instrument, with specific fields for frequent causes of emergency paediatric visits such as colds, otitis, eye irritation, cough, and asthma. In addition, the reasons for the visits were classified as upper airways diseases, lower airways diseases, and/or acute respiratory infections. It was necessary to create this original instrument because the medical records did not mention the International Classification of Diseases (ICD) or any other classification of the symptoms and clinical diagnoses that would allow data standardization.

Due to the various forms of clinical manifestations caused by the reduction in the bronchial lumen and the absence of standardized annotations, the field "asthma" was checked whenever the medical records indicated bronchial asthma, bronchiolitis, chest wheezing or wheezing, which are frequently related to obstructive diseases of the airways in children. This procedure was necessary because the medical annotations frequently referred merely to a sign or symptom, without mentioning a probable diagnosis.

Hourly concentrations of particulate matter with aerodynamic volume of up to 10 microns $\left(\mathrm{PM}_{10}\right)$, sulphur dioxide $\left(\mathrm{SO}_{2}\right)$, nitrogen dioxide $\left(\mathrm{NO}_{2}\right)$, carbon monoxide $(\mathrm{CO})$, and ozone $\left(\mathrm{O}_{3}\right)$ were recorded from an automatic monitoring station located centrally in Jacarepaguá, and the daily averages of these pollutants were used as the indicators of the population's exposure to air pollution. The following criteria were used in order to obtain the daily exposure for each pollutant: for $\mathrm{PM}_{10}, \mathrm{SO}_{2}$, and $\mathrm{NO}_{2}$, at least $75 \%$ of the hourly measures should be observed; for $\mathrm{O}_{3}$, the maximum concentration during daylight time (6 am to $6 \mathrm{pm}$ ) was taken when at least $75 \%$ of the measures were observed; and for $\mathrm{CO}$, the maximum of an 8-hour running average if $75 \%$ of the daily data were available.

During the study period, technical problems caused several interruptions in the monitoring of pollutants. By the end, there were records for 246 days of $\mathrm{PM}_{10}, 201$ days of $\mathrm{NO}_{2}, 244$ days of $\mathrm{CO}$, 237 days of $\mathrm{O}_{3}$, and only 194 days of $\mathrm{SO}_{2}$. Given the important gap in the environmental data on $\mathrm{SO}_{2}$, the choice was made not to analyse the respiratory effects of this pollutant.

Flaws occurred in monitoring, both in short sequences of days and long periods of several consecutive days: 08-30 September 2002, $1^{\text {st }}$ December 2002 to 15 January 2003, and 10 February 2003 to 16 March 2003. In order to minimize possible spurious associations, information was imputed from monitors located in other areas of the city for gaps on single days or short periods. The high correlation between the environmental pollutant levels measured in Jacarepaguá and these other areas allowed the use of a data imputation procedure. The methodology adopted in the imputation process was similar to that described by Junger et al. 11, in which the estimates are obtained by the spatial correlation between the level of the same pollutant in the different 
monitoring stations and the autocorrelation for this pollutant level in the same monitoring station over time.

The choice to replace only the gaps from short intervals meant that the total observation period for $\mathrm{PM}_{10}$ and $\mathrm{CO}$ was 262 out of 365 days. The amount of data was smaller for $\mathrm{NO}_{2}$ and $\mathrm{O}_{3}$, 250 and 248 respectively, because the replacement option only included one station.

Daily data on meteorological conditions: relative humidity and minimum, mean and maximum temperatures were measured in a station located close to the study region. Information on weather conditions from the current day, the two previous days, and the mean for the two previous days were used in the analysis. Rainfall was also considered in the model due to the occasional showers during the summer time, which often cause floods in some areas of the city and, therefore, limits people's access to health care units.

The outcome variable - emergency paediatric visits due to obstructive bronchial symptoms - was stratified by age brackets: $\leq 2$ years, 2-6 years, and 6-12 years. The exposure variables were mean daily concentration of the air pollutants $\mathrm{PM}_{10}, \mathrm{NO}_{2}, \mathrm{CO}$, and $\mathrm{O}_{3}$. Time trend, seasonality, weather conditions, anomalous days over the course of the year, epidemics of respiratory infections were the potential confounding variables regarded in the model. A Poisson regression model was used, since the outcome variable consisted of counts of events.

In the estimation of the effects of air pollutants on health, the confounders showing daily fluctuations needed to be accounted for. Generalized additive models (GAM) have been used for this purpose, since they are quite flexible, allowing for the inclusion oif parametric and nonparametric structures in the same model. This study used splines (data smoothing functions) to adjust for the effects of time trends and longterm seasonality as well as the effects of meteorological variables.

The days of the week that showed anomalous behaviour, like weekends, holidays, days between holidays and weekends, and days on which the 2002 Football World Cup matches were held were also included in the regression models as indicator variables.

It was not possible to estimate the effect of airborne allergens (like pollen and fungi) in relation to air pollutants, since no systematic records were found in Rio de Janeiro.

To investigate respiratory infection epidemics, we drew on records for paediatric hospital admissions due to pneumonia in the city of Rio de Janeiro from April 2002 to March 2003, obtained from the database of the Unified National
Health System (DATASUS; http://www.datasus. gov.br). Diagnoses of pneumonias were selected according to the ICD, $10^{\text {th }}$ revision (ICD-10: J12 to J18) ${ }^{12}$. The methodology used in the determination of epidemic periods was similar to that reported by Braga et al. 13. Adjustment of this variable used cubic polynomials for each epidemic period.

Acute respiratory manifestations related to air pollutants can display several days of lag in relation to exposure. This study analysed the air pollution levels on the day of the paediatric visit (D0) and the three previous days (D1, D2, D3). The cumulative effect was evaluated with the running means of the pollutant levels from two to seven days (mm2, mm3, mm4, mm5, mm6, mm7).

Poisson regression equations directly produce relative risk values. In this paper risk values correspond to an increase of $10 \mu \mathrm{g} / \mathrm{m}^{3}$ in each pollutant level analysed separately, with the exception of CO, for which an increase of $1,000 \mu \mathrm{g} / \mathrm{m}^{3}$ was considered. A 5\% significance level was adopted for the study. Results were also reported as percentage variation in paediatric visits.

The study protocol was submitted to the Research Ethics Committee of the Social Medicine Institute at the State University of Rio de Janeiro and was approved at a meeting held on 19 June 2002.

\section{Results}

From April 2002 to March 2003, there were 45,595 emergency paediatric visits due to respiratory disorders. Symptoms of lower airways obstruction accounted for approximately $42 \%$ of all visits due to lower airways symptoms. In relation to children's age, those under 2 years of age comprised 2,841 visits and those from aged between 2 and 6 and over 6 comprised 2,893 and 1,067 visits, respectively.

During the study period there was no violation of the air quality standards recommended by the National Environmental Commission (CONAMA). The CONAMA resolution states that the primary standards are those pollutant concentrations that if exceeded may cause harmful effects on the exposed population. The recommended primary limit for $\mathrm{PM}_{10}$ is $150 \mu \mathrm{g} / \mathrm{m}^{3}$, for $\mathrm{O}_{3}$ is $160 \mu \mathrm{g} / \mathrm{m}^{3}$, for $\mathrm{NO}_{2}$ is $320 \mu \mathrm{g} / \mathrm{m}^{3}$, and for CO $10,000 \mu \mathrm{g} / \mathrm{m}^{3} 14$. Table 1 shows the descriptive statistics for the environmental and health variables.

The Pearson correlation coefficients between air pollutants (with the exception of $\mathrm{CO}$ and $\mathrm{O}_{3}$ ) were positive and statistically significant. The highest value was 0.33 , between $\mathrm{CO}$ and $\mathrm{PM}_{10}$. 
Descriptive statistics for environmental variables and emergency paediatric visits due to symptoms of bronchial obstruction, by age range, between April 2002 and March 2003

\begin{tabular}{|c|c|c|c|c|c|c|c|c|}
\hline & $\mathrm{n}$ & $\begin{array}{l}\text { Percentage of } \\
\text { imputed data }\end{array}$ & $\begin{array}{l}\text { Mean } \\
\text { (SD) }\end{array}$ & Minimum & p25 & p50 & p75 & Maximum \\
\hline Total & 262 & 0 & 21.58 (10.49) & 4 & 14 & 20 & 27 & 61 \\
\hline \multicolumn{9}{|l|}{ Years } \\
\hline $0-2$ & 262 & 0 & $8.22(5.4)$ & 0 & 4 & 7 & 10 & 31 \\
\hline $2-6$ & 262 & 0 & $8.44(4.52)$ & 0 & 5 & 8 & 11 & 23 \\
\hline $6-12$ & 262 & 0 & $3.36(2.39)$ & 0 & 2 & 3 & 5 & 12 \\
\hline \multicolumn{9}{|l|}{ Temperature } \\
\hline Minimum & 365 & 0 & $22.14(2.97)$ & 15 & 19.8 & 22.5 & 24.4 & 28.6 \\
\hline Average & 365 & 0 & $26.31(3.08)$ & 18.01 & 24.34 & 26.36 & 28.64 & 32.7 \\
\hline Maximum & 365 & 0 & $31.16(4.04)$ & 19 & 29 & 31.3 & 34 & 40 \\
\hline Humidity (\%) & 365 & 0 & $76.42(8.11)$ & 52.58 & 70.75 & 76.37 & 81.54 & 95.5 \\
\hline Rainfall (mm) & 365 & 0 & 3.59 (10.30) & 0 & 0 & 0 & 0.72 & 76.87 \\
\hline $\mathrm{PM}_{10}\left(\mu \mathrm{g} / \mathrm{m}^{3}\right)$ & 262 & 6.11 & 34.67 (12.49) & 11.22 & 25.65 & 32.82 & 41.53 & 79.04 \\
\hline $\mathrm{CO}\left(1,000 \mu \mathrm{g} / \mathrm{m}^{3}\right)$ & 262 & 6.87 & $1.37(0.34)$ & 0.35 & 1.17 & 1.39 & 1.6 & 2.38 \\
\hline $\mathrm{NO}_{2}\left(\mu \mathrm{g} / \mathrm{m}^{3}\right)$ & 250 & 19.6 & $62.78(32.96)$ & 9.6 & 38.5 & 59 & 81.45 & 209.8 \\
\hline $\mathrm{O}_{3}\left(\mu \mathrm{g} / \mathrm{m}^{3}\right)$ & 248 & 4.43 & $36.78(21.75)$ & 4 & 19.87 & 31.85 & 50.17 & 123.9 \\
\hline
\end{tabular}

$\mathrm{n}$ : total number of observation days; SD: standard deviation; p: percentile.

In children less than 2 years of age, an increase of $10 \mu \mathrm{g} / \mathrm{m}^{3}$ in the environmental concentration of $\mathrm{PM}_{10}$ was associated with an increase of nearly $7 \%$ in the demand for emergency paediatric care due to airways obstruction $(\mathrm{p}<0.01)$. The same value for $\mathrm{O}_{3}$ exposure led to a smaller effect, some $3 \%$, in the same age bracket, with marginal statistical significance $(p<0.06)$. The estimates of acute respiratory effects in the children as a whole and in the other age groups did not show positive or statistically significant associations.

Figure 1 provides graphic representation of the percentage variations in all emergency paediatric visits due to the symptoms of bronchial obstruction in children less than 2 years of age.

All the results are summarized in Table 2.

\section{Discussion}

The results suggest that exposure to air pollutants was associated with a significant increase in emergency paediatric visits due to symptoms of bronchial obstruction in children under the age of 2 .

Statistical analysis in ecological studies with daily time series data, considering long and medium-term temporal variations, requires that the series be sufficiently long for the phenomena to be shown and the results unbiased. The observa- tion period, with a maximum of 262 days for the majority of the pollutants, was the principal limitation in this study, although gaps in monitoring of pollutants were not related to the air pollution levels.

Farhat et al. 15, Atkinson et al. 16 and Lin et al. 17 found positive and significant associations between exposure to air pollutants and symptoms of bronchial obstruction in children, without taking age into account. Conversely, in this study, the absence of a significant result when all age ranges were analysed together may have been due to a dilution of the effects since the outcome included the entire paediatric population.

The impact of the exposure to $\mathrm{PM}_{10}$ was concentrated in children under 2 . This age bracket has specific characteristics that distinguishes it from others ages. Therefore, our findings highlight the importance of this specificity in the outcome. One hypothesis is that air pollution did not influence the demand for emergency paediatric care due to bronchial asthma (a common immunological disease in older children). On the other hand, in children under 2 years of age, the demand for medical care for symptoms of bronchial obstruction, frequently associated with viral agents in this age group, was associated with $\mathrm{PM}_{10}$ and also with $\mathrm{O}_{3}$ (although a weaker association in the latter case). One can conclude 
Percentage variation (RR) and 95\% confidence intervals for paediatric visits due to obstructive bronchial symptoms in children less than 2 years of age.

1a) $\mathrm{PM}_{10}$

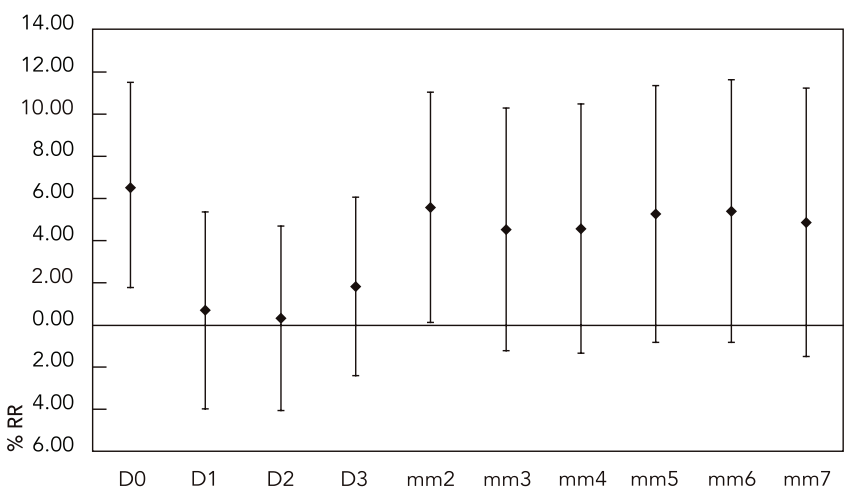

1c) $\mathrm{CO}$

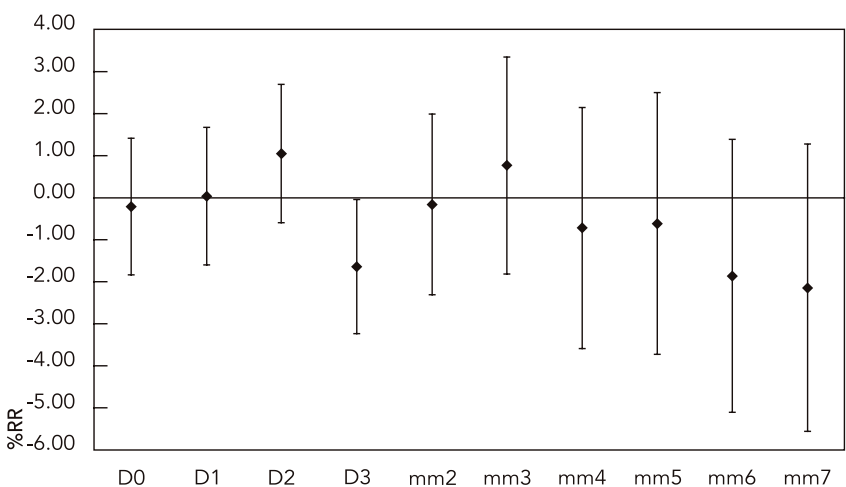

1b) $\mathrm{NO}_{2}$

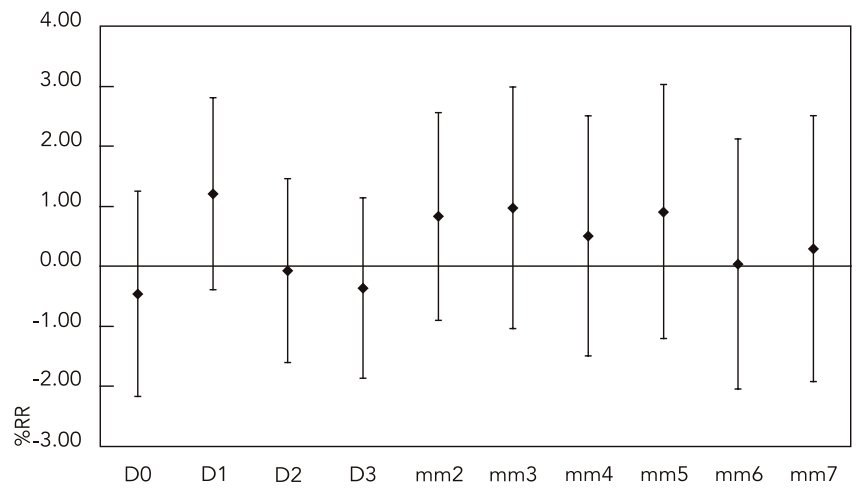

1d) $\mathrm{O}_{3}$

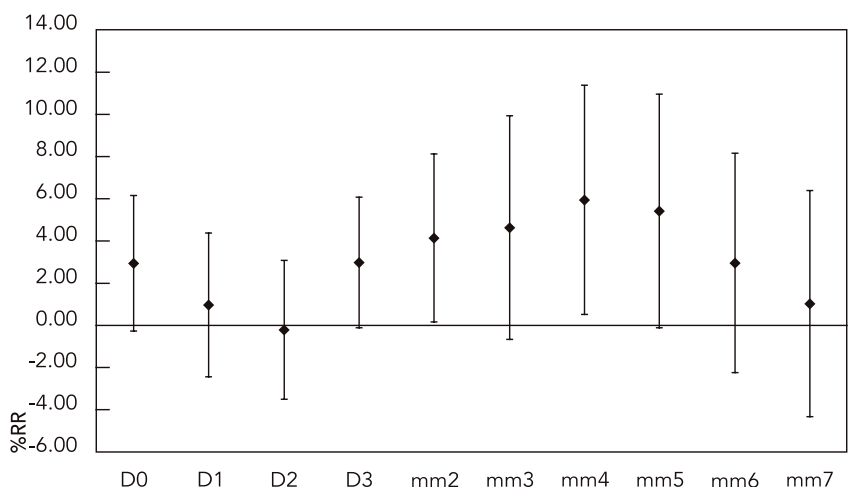

Note: effects on the same day (D0), 1 day later (D1), 2 days later (D2), 3 days later (D3), and the moving mean of the concentrations of pollutants for 2, 3, 4, 5, 6 , and 7 days (mm2, mm3, mm4, mm5, mm6, mm7, respectively).

that the reduced dimensions of airways in smaller children, exacerbating the clinical manifestations of viral infection, made these children more susceptible to the effects of pollutants than the immune alterations characteristic of bronchial asthma. This result can also be explained by the parents' greater concern over health problems in younger children, demanding immediate medical care, even for less severe cases. On the other hand, in older children, the respiratory symptoms that can appear after exposure either were not severe enough to require emergency care or were treated later, outside the observation period.

Few studies have taken childhood anatomical and functional variations into consideration, categorizing the respiratory effects of air pollutants by age bracket. This limits a broad evaluation of the consistency of results. Braga et al. 18, in São Paulo, Brazil, investigated hospital admissions due to respiratory causes according to four age groups of children and adolescents. There were more admissions for increased exposure to $\mathrm{PM}_{10}, \mathrm{O}_{3}, \mathrm{SO}_{2}, \mathrm{CO}$, and $\mathrm{NO}_{2}$ among children aged under 2, equivalent to an interquartile interval. A greater effect occurred with $\mathrm{PM}_{10}$, and with the exception of $\mathrm{O}_{3}$, it was possible to reject the null hypothesis with $99.9 \%$ probability. However, the study did not analyse the respiratory diagnoses related to the admissions, which precludes comparison with our study in Jacarepaguá. 
Percentage variation (RR) and $95 \%$ confidence intervals $(95 \% \mathrm{Cl})$ for paediatric visits due to obstructive bronchial symptoms in children.

\begin{tabular}{|c|c|c|c|c|}
\hline \multirow[t]{3}{*}{ Outcome/Exposure } & \multicolumn{4}{|c|}{ Pollutant } \\
\hline & $\mathrm{PM}_{10}$ & $\mathrm{CO}$ & $\mathrm{NO}_{2}$ & $\mathrm{O}_{3}$ \\
\hline & RR (95\%Cl) & RR (95\%Cl) & RR (95\%Cl) & RR (95\%Cl) \\
\hline \multicolumn{5}{|l|}{ All ages } \\
\hline Concurrent day & $1.54(-1.50 ; 4.69)$ & $-0.25(-1.33 ; 0.84)$ & $-0.35(-1.41 ; 0.72)$ & $0.01(-1.97 ; 2.04)$ \\
\hline 1 day lag & $0.98(-2.20 ; 4.27)$ & $0.04(-1.05 ; 1.14)$ & $0.58(-0.46 ; 1.64)$ & $-0.80(-2.94 ; 1.39)$ \\
\hline 2 day lag & $-0.31(-3.49 ; 2.97)$ & $0.91(-0.19 ; 2.03)$ & $0.03(-1.07 ; 1.14)$ & $-0.80(-3.21 ; 1.66)$ \\
\hline 3 day lag & $-0.35(-3.26 ; 2.64)$ & $-0.28(-1.41 ; 0.86)$ & $-0.04(-1.03 ; 0.97)$ & $1.02(-1.03 ; 3.11)$ \\
\hline 2 day average & $1.62(-1.82 ; 5.19)$ & $-0.19(-1.57 ; 1.22)$ & $0.26(-0.84 ; 1.37)$ & $-0.60(-2.88 ; 1.73)$ \\
\hline 3 day average & $1.36(-2.46 ; 5.34)$ & $0.52(-1.12 ; 2.20)$ & $0.25(-1.05 ; 1.55)$ & $-0.66(-3.76 ; 2.54)$ \\
\hline 4 day average & $1.26(-2.73 ; 5.43)$ & $0.24(-1.64 ; 2.15)$ & $0.51(-0.83 ; 1.88)$ & $0.78(-2.62 ; 4.29)$ \\
\hline 5 day average & $1.45(-2.64 ; 5.70)$ & $0.46(-1.60 ; 2.57)$ & $0.42(-0.99 ; 1.85)$ & $0.82(-2.69 ; 4.46)$ \\
\hline 6 day average & $1.36(-2.79 ; 5.69)$ & $0.08(-2.10 ; 2.30)$ & $0.33(-1.07 ; 1.75)$ & $0.18(-3.21 ; 3.69)$ \\
\hline 7 day average & $1.28(-2.97 ; 5.71)$ & $-0.10(-2.38 ; 2.23)$ & $0.51(-0.98 ; 2.03)$ & $-1.07(-4.56 ; 2.55)$ \\
\hline \multicolumn{5}{|l|}{$<2$ years old } \\
\hline Concurrent day & $6.53(1.78 ; 11.51)$ & $-0.21(-1.82 ; 1.42)$ & $-0.46(-2.16 ; 1.26)$ & $2.90(-0.27 ; 6.18)$ \\
\hline 1 day lag & $0.60(-3.98 ; 5.39)$ & $0.03(-1.60 ; 1.69)$ & $1.20(-0.39 ; 2.82)$ & $0.92(-2.43 ; 4.38)$ \\
\hline 2 day lag & $0.24(-4.04 ; 4.72)$ & $1.04(-0.59 ; 2.70)$ & $-0.07(-1.59 ; 1.47)$ & $-0.25(-3.48 ; 3.09)$ \\
\hline 3 day lag & $1.76(-2.39 ; 6.09)$ & $-1.64(-3.22 ;-0.03)$ & $-0.36(-1.85 ; 1.15)$ & $2.94(-0.11 ; 6.08)$ \\
\hline 2 day average & $5.44(0.12 ; 11.04)$ & $-0.17(-2.30 ; 2.00)$ & $0.82(-0.89 ; 2.57)$ & $4.08(0.17 ; 8.14)$ \\
\hline 3 day average & $4.39(-1.22 ; 10.31)$ & $0.74(-1.80 ; 3.35)$ & $0.96(-1.03 ; 3.00)$ & $4.52(-0.65 ; 9.95)$ \\
\hline 4 day average & $4.40(-1.34 ; 10.49)$ & $-0.76(-3.58 ; 2.15)$ & $0.49(-1.49 ; 2.52)$ & $5.82(0.53 ; 11.39)$ \\
\hline 5 day average & $5.10(-0.80 ; 11.36)$ & $-0.65(-3.71 ; 2.51)$ & $0.90(-1.19 ; 3.03)$ & $5.29(-0.09 ; 10.97)$ \\
\hline 6 day average & $5.22(-0.83 ; 11.63)$ & $-1.90(-5.10 ; 1.41)$ & $0.03(-2.03 ; 1.41)$ & $2.85(-2.21 ; 8.17)$ \\
\hline 7 day average & $4.68(-1.49 ; 11.23)$ & $-2.19(-5.54 ; 1.28)$ & $0.27(-1.91 ; 2.51)$ & $0.90(-4.30 ; 6.39)$ \\
\hline \multicolumn{5}{|l|}{ 2-6 years old } \\
\hline Concurrent day & $-1.67(-5.53 ; 2.36)$ & $-0.15(-1.60 ; 1.32)$ & $0.44(-1.07 ; 1.97)$ & $-1.94(-4.71 ; 0.92)$ \\
\hline 1 day lag & $0.90(-3.37 ; 5.36)$ & $0.84(-0.63 ; 2.34)$ & $0.43(-1.09 ; 1.96)$ & $-2.85(-5.87 ; 0.27)$ \\
\hline 2 day lag & $0.70(-3.57 ; 5.17)$ & $1.77(0.28 ; 3.27)$ & $1.31(-0.27 ; 2.92)$ & $-2.79(-6.14 ; 0.68)$ \\
\hline 3 day lag & $-0.24(-4.10 ; 3.77)$ & $1.54(0.01 ; 3.09)$ & $1.17(-0.24 ; 2.60)$ & $0.71(-2.26 ; 3.77)$ \\
\hline 2 day average & $-0.74(-5.21 ; 3.95)$ & $0.58(-1.31 ; 2.49)$ & $0.40(-1.19 ; 2.01)$ & $-3.79(-6.97 ;-0.50)$ \\
\hline 3 day average & $-0.38(-5.39 ; 4.90)$ & $1.95(-0.30 ; 4.25)$ & $1.23(-0.63 ; 3.12)$ & $-5.38(-9.57 ;-0.99)$ \\
\hline 4 day average & $-0.10(-5.33 ; 5.43)$ & $3.02(0.42 ; 5.68)$ & $1.63(-0.34 ; 3.63)$ & $-4.75(-9.36 ; 0.10)$ \\
\hline 5 day average & $-0.32(-5.63 ; 5.30)$ & $3.00(0.16 ; 5.92)$ & $1.70(-0.37 ; 3.82)$ & $-3.45(-8.35 ; 1.71)$ \\
\hline 6 day average & $-0.93(-6.33 ; 4.77)$ & $3.06(0.05 ; 6.15)$ & $1.94(-0.14 ; 4.06)$ & $-2.85(-7.63 ; 2.19)$ \\
\hline 7 day average & $-1.56(-7.07 ; 4.27)$ & $2.28(-0.85 ; 5.51)$ & $2.15(-0.09 ; 4.44)$ & $-4.88(-9.81 ; 0.31)$ \\
\hline \multicolumn{5}{|l|}{ 6-12 years old } \\
\hline Concurrent day & $3.13(-3.77 ; 10.53)$ & $-2.06(-4.24 ; 0.16)$ & $-1.71(-4.36 ; 1.00)$ & $-0.39(-4.59 ; 4.01)$ \\
\hline 1 day lag & $5.58(-1.45 ; 13.11)$ & $-0.48(-2.74 ; 1.83)$ & $-0.20(-2.96 ; 2.65)$ & $-0.17(-4.88 ; 4.76)$ \\
\hline 2 day lag & $1.82(-4.91 ; 9.03)$ & $-0.79(-3.07 ; 1.54)$ & $-1.85(-4.41 ; 0.78)$ & $4.29(-1.01 ; 9.88)$ \\
\hline 3 day lag & $-0.42(-6.63 ; 6.21)$ & $-0.30(-2.56 ; 2.02)$ & $-1.34(-3.88 ; 1.27)$ & $-1.12(-5.74 ; 3.73)$ \\
\hline 2 day average & $5.50(-2.25 ; 13.87)$ & $-2.18(-5.01 ; 0.73)$ & $-1.20(-4.16 ; 1.84)$ & $-0.71(-5.79 ; 4.64)$ \\
\hline 3 day average & $5.48(-2.96 ; 14.66)$ & $-2.69(-6.04 ; 0.77)$ & $-2.34(-5.49 ; 0.93)$ & $3.32(-3.65 ; 10.79)$ \\
\hline 4 day average & $4.50(-4.21 ; 14.01)$ & $-3.09(-6.85 ; 0.82)$ & $-2.19(-5.52 ; 1.26)$ & $3.87(-3.89 ; 12.26)$ \\
\hline 5 day average & $4.68(-4.23 ; 14.41)$ & $-1.69(-5.93 ; 2.74)$ & $-2.77(-6.25 ; 0.84)$ & $1.28(-6.67 ; 9.91)$ \\
\hline 6 day average & $5.01(-4.17 ; 15.07)$ & $-2.17(-6.77 ; 2.64)$ & $-2.71(-6.35 ; 1.09)$ & $1.91(-6.30 ; 10.84)$ \\
\hline
\end{tabular}

An increase in the concentration of $\mathrm{PM}_{10}$ was associated with more emergency visits in children aged between 6 and 12. In this age group, obstructive airway symptoms are more likely the result of the immune phenomena of bronchial asthma than in younger children. This effect, although not statistically significant, was observed on the day of exposure, on the previous days, and 
taking accumulated exposure indicators into account. The small daily mean number of visits by children in this group (some three per day) may have been insufficient to reach statistical power.

As in our study in Rio de Janeiro, in Seattle, U.S.A. 19,20 and Santa Clara County, California, U.S.A. $21, \mathrm{PM}_{10}$ was associated with increased emergency paediatric visits due to acute exacerbation of bronchial asthma. Recent studies have suggested that increased use of diesel fuel in automobiles in large metropolises and the particles produced by diesel exhaust may be associated with the increase in allergic respiratory diseases 22 .

As for the impact of air pollutants on bronchial asthma, $\mathrm{O}_{3}$ is the most extensively investigated agent ${ }^{5}$. Numerous epidemiological studies have highlighted the importance of $\mathrm{O}_{3}$ and demonstrated a relationship between its environmental concentration and bouts of acute bronchial asthma 23,24,25,26,27,28,29.

In principle, the body's response to acute aggressions in the airways does not comply with the clinical manifestations observed in a 24-hour period, unless the effects show very low intensity. Similar epidemiological studies have shown that the greater demand for emergency care remains for a few days after the exposure to higher levels of air pollution 30,31 . In Jacarepaguá, during the study period, lower levels of environmental pollutants were observed, and is possible that the effect due to an increase in levels of the exposure may have been brief and mild, hence, quickly solved without the need for medical care. In addition, it is possible that the more susceptible children might have shown greater demand for medical assistance.

The temporal distribution of the paediatric visits in Jacarepaguá suggests higher incidence of symptoms at the beginning of winter in children of all age brackets. Another peak in paediatric visits is observed in spring, only in the series for children over 2 years of age. Physiologically, the allergic reactions that are characteristic of bronchial asthma appear after the preschool period, and in our study they could correspond to the second peak of bronchial symptoms in older children only. Pollens are known respiratory allergens, and this time of year corresponds to the pollination stage of several species of flowers in many countries when the amount of pollen in the air increases followed by a higher incidence of respiratory symptoms in allergic individuals. Still, the inclusion of indicators of environmental pollen levels as a possible confounding factor in the association between air pollutants and respiratory effects has not always caused significant alterations 23,32,33. Further, it was not possible to assess this effect in the current study because the available information is conflicting on pollen species and periods of pollination, and the environmental pollen levels are not systematically monitored in Rio de Janeiro.

The sources of pollutants in Jacarepaguá are particular, diverse, and different from other areas of the city of Rio de Janeiro and may yield an inhaled air composition that at least partially explains the observed results. Apparently, the burning of fossil fuels in vehicle engines and industrial emissions share the responsibility for the composition of the inhaled air pollutants in Jacarepaguá. The large industrial park sited in this area probably contributes heavily to the air pollution levels, since there are some two hundred installed plants 34

An information bias may arise when the dependent variable includes information from emergency medical services. When paediatric populations are involved, the errors can result from both mistaken information supplied by the children's parents or guardians and the hasty and erroneous medical diagnostic impressions that are common in emergency settings. Diagnostic errors are frequent in bronchial asthma due to the variety of clinical symptoms that asthma can produce in children 27 . However, this bias is generally non-differential, since during the medical consultation the health professional is unaware of air pollutant levels. In a study in São Paulo, all the clinical diagnoses were confirmed by two physicians, which probably reduced the incidence of bias in the study 17 .

In order to decrease respiratory diagnostic errors arising from the similarity between manifestations of viral infections and bronchial asthma, Fauroux et al. 26 and Chew et al. 35 did not include younger children in the study population and Farhat et al. 15 adopted the term "obstructive diseases" to designate manifestations of bronchial obstruction in childhood in all age brackets. In the current study we chose to use the term "obstructive symptoms of the airways" for respiratory manifestations due to both aetiologies.

It is worthy noting that Rio de Janeiro city shows relevant local differences regarding its topography, and the city contains three air basins. Jacarepaguá is located in air basin II, so the transport mechanisms implicated in the dispersion of pollutants may differ across the city. Therefore, the domain of the study may not be extendible to the entire city due to differences in the composition of the particulate matter. Besides, it is known that $\mathrm{PM}_{10}$ concentrations also show local variations.

Despite the gaps in monitoring of the air pollutants, the increase of nearly $7 \%$ in the number 
of daily emergency room visits due to obstructive symptoms of the airways associated with environmental levels of $\mathrm{PM}_{10}$ indicates the existence of an important public health problem in the city of Rio de Janeiro. A borderline-significant increase of $3 \%$ in emergency paediatric visits due to ozone indicates the need to identify and attenuate the sources of air pollution in Jacarepaguá. A major contribution will certainly come from spatial analysis of these data, which is under development.

\section{Resumo}

O objetivo deste trabalho foi estimar a associação entre os niveis dos poluentes atmosféricos e sintomas respiratórios em crianças. Foi realizado um estudo ecológico de séries temporais, entre abril de 2002 e março de 2003, com dados diários de $\mathrm{PM}_{10}, \mathrm{SO}_{2}, \mathrm{CO}, \mathrm{NO}_{2}$ e $\mathrm{O}_{3}$ e dos atendimentos pediátricos de emergência ocasionados por sintomas de obstrução brônquica. As variáveis de confusão foram: tendência temporal, sazonalidade, fatores meteorológicos, infecções respiratórias e os efeitos dos finais de semana e feriados. Regressão de Poisson semiparamétrica foi usada para modelar as séries temporais. Curvas suaves, splines, variáveis indicadoras e polinômios cúbicos foram empregadas para corrigir os efeitos dos fatores de confundimento. Foi adotado o nível de significância de 5\%. Um incremento estatisticamente significativo dos atendimentos, de 6,7\%, esteve associado com $P_{10}$ nas crianças menores do que dois anos. Associação positiva com o $\mathrm{O}_{3}$, em torno de 3\%, nessa faixa etária, teve significado estatístico limítrofe $(p<0,06)$. Esses resultados evidenciam um problema de saúde pública não reconhecido no Rio de Janeiro, Brasil, que reforça a necessidade de identificação das principais fontes de poluição.

\section{Contributors}

M. Moura was in charge of all steps of the study and also in planning and elaborating the manuscript, data analyses, and drafting of the manuscript. W. L. Junger and A. Ponce de Leon were in charge of planning the study, data analyses and revision of the manuscript. G. A. S. Mendonça participated in planning the study and in the revision of the manuscript.

\section{Acknowledgments}

This study was funded by the Brazilian Ministry for the Environment (2001CV000044-SQA/MMA). 


\section{References}

1. O'Connell E. Pediatric allergy: a brief review of risk factors associated with developing allergic disease in childhood. Ann Allergy Asthma Immunol 2003; 90(6 Suppl 3):53-8.

2. Ball TM, Castro-Rodriguez JA, Griffith KA, Holberg CJ, Martinez FD, Wright AL. Siblings, day-care attendance, and the risk of asthma and wheezing during childhood. N Engl J Med 2000; 343:538-43.

3. Ramsey CD, Celedón JC. The hygiene hypothesis and asthma. Curr Opin Pulm Med 2004; 11:14-20.

4. Masoli M, Fabian D, Holt S, Beasley R; Global Initiative for Asthma (GINA) Program. The global burden of asthma report: executive summary of the GINA Dissemination Committee report. Allergy 2004; 59:469-78.

5. Bernstein JA, Alexis N, Barnes C, Bernstein IL, Bernstein JA, Nel A, et al. Health effects of air pollution. J Allergy Clin Immunol 2004; 114:1116-23.

6. Hiltermann TJ, Stolk J, van der Zee SC, Brunekreef B, de Bruijne CR, Fisher PH, et al. Asthma Severity and Susceptibility to Air Pollution. Eur Respir J 1998; 11:686-93.

7. Wright AL. Epidemiology of asthma and recurrent wheeze in childhood. Clin Rev Allergy Immunol 2002; 22:33-44.

8. Gern JE. The spectrum of severe wheezing in childhood. J Allergy Clin Immunol 2004; 114:236-8.

9. Buchdahl R, Parker A, Stebbings T, Babiker A. Association between air pollution and acute childhood wheezy episodes: prospective observational study. BMJ 1996; 312:661-5.

10. Boechat JL, Rios JL, Sant'anna CC, França AT. Prevalência e gravidade de sintomas relacionados à asma em escolares e adolescentes no município de Duque de Caxias, Rio de Janeiro. J Bras Pneumol 2005; 31:111-7.

11. Junger W, Santos N, Ponce de Leon A. Missing data imputation in multivariate time series via EM algorithm. Cadernos do IME 2003; 15:8-21.

12. Organização Mundial da Saúde. Classificação estatística internacional de doenças e problemas relacionados à saúde, 10a revisão. São Paulo: Centro Colaborador da OMS para a Classificação de Doenças em Português; 1995.

13. Braga ALF, Zannobetti A, Schwartz J. Do respiratory epidemics confound the association between air pollution and daily deaths? Eur Respir J 2000; 16:723-8.

14. Brasil. Resolução CONAMA no. 003, de 28 de junho de 1990. Diário Oficial da União 1990; 22 ago.

15. Farhat SCL, Paulo RL, Shimoda TM, Conceição GM, Lin CA, Braga ALF, et al. Effect of air pollution on pediatric respiratory emergency room visits and hospital admission. Braz J Med Biol Res 2005; 38:227-35.

16. Atkinson RW, Strachan DP. Role of outdoor aeroallergens in asthma exacerbations: epidemiological evidence. Thorax 2004; 59:277-8.

17. Lin CA, Martins MA, Farhat SC, Pope 3rd CA, Conceição GM, Anastácio VM, et al. Air pollution and respiratory illness of children in São Paulo, Brazil. Paediatr Perinat Epidemiol 1999; 13:475-88.
18. Braga AL, Saldiva PH, Pereira LA, Menezes JJ, Conceição GM, Lin CA, et al. Health effects of air pollution exposure on children and adolescents in São Paulo, Brazil. Pediatr Pulmonol 2001; 31:106-13.

19. Norris G, YoungPong SN, Koening JQ, Larson TV, Sheppard L, Stout JW. An association between fine particles and asthma emergency department visits for children in Seattle. Environ Health Perspect 1999; 107:489-93.

20. Schwartz J, Larson TV, Pierson WE, Koenig JQ. Particulate air pollution and hospital emergency room visits for asthma in Seattle. Am Rev Respir Dis 1993; 147:826-31.

21. Lipsett M, Hurley S, Ostro B. Air pollution and emergency room visits for asthma in Santa Clara County, California. Environ Health Perspect 1997; 105:216-22.

22. Pandya RJ, Solomon G, Kinner A, Balmes JR. Diesel exhaust and asthma: hypotheses and molecular mechanism of action. Environ Health Perspect 2002; 110 Suppl 1:103-12.

23. Galán I, Tobías A, Banegas JR, Aránguez E. Shortterm effects of air pollution on daily asthma emergency room admissions. Eur Respir J 2003; 22: 802-8.

24. Sunyer J, Spix C, Quénel P, Ponce de Leon A, Pönka A, Barumandzadeh T, et al. Urban air pollution and emergency admissions for asthma in four European cities: the APHEA Project. Thorax 1997; 52:760-5.

25. Tenias JM, Ballester F, Rivera ML. Association between hospital emergency visits for asthma and air pollution in Valencia, Spain. Occup Environ Med 1998; 55:541-7.

26. Fauroux B, Sampil M, Quénel P, Lemoullec Y. Ozone: a trigger for hospital pediatric asthma emergency room visits. Pediatr Pulmonol 2000; 30:41-6.

27. Romieu I, Meneses F, Sienra-Monge JJ, Huerta J, Velasco SR, White MC, et al. Effects of urban air pollutants on emergency visits for childhood asthma in Mexico City. Am J Epidemiol 1995; 141: 546-53.

28. Stieb DM, Burnett RT, Beveridge RC, Brook JR. Association between ozone and asthma emergency department visits in Saint John, New Brunswick, Canada. Environ Health Perspect 1996; 104:1354-60.

29. Yang W, Jennison BL, Omaye ST. Air pollution and asthma emergency room visits in Reno, Nevada. Inhal Toxicol 1997; 9:15-29.

30. Peel JL, Tolbert PE, Klein M, Metzger KB, Flanders WD, Todd K, et al. Ambient air pollution and respiratory emergency department visits. Epidemiology $2005 ; 16: 164-74$.

31. Hernández Cadena L, Téllez Rojo MM, Sanín Aguirre LH, Lacasaña Navarro M, Campos A, Romieu I. Relación entre consultas a urgencias por enfermedad respiratoria y contaminación atmosférica en Ciudad Juárez, Chihuahua. Salud Pública Méx 2000; 42:288-97. 
32. Anderson HR, Ponce de Leon A, Bland JM, Bower JS, Emberlin J, Strachan DP. Air pollution, pollens, and daily admissions for asthma in London 1987 92. Thorax 1998; 53:842-8.

33. Hajat S, Haines A, Goubet SA, Atkinson RW, Anderson HR. Associations of air pollution with daily GP consultations for asthma and other lower respiratory conditions in London. Thorax 1999; 54: 597-605.
34. Federação das Indústrias do Rio de Janeiro. Cadastro industrial do Estado do Rio de Janeiro. Rio de Janeiro: Federação das Indústrias do Rio de Janeiro; 2005.

35. Chew FT, Goh DYT, Ooi BC, Saharom R, Hui JK, Lee BW. Association of ambient air-pollution levels with acute asthma exacerbation among children in Singapore. Allergy 1999; 54:320-9.

Submitted on $06 / \mathrm{Jul} / 2007$

Final version resubmitted on $07 / \mathrm{Jan} / 2008$

Approved on 28/Mar/2008 